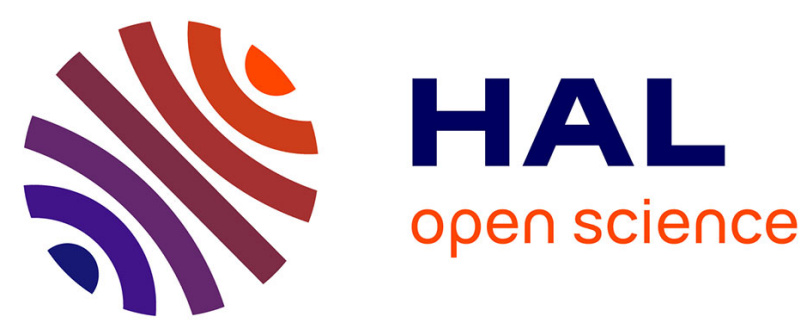

\title{
Hydration due to high-T brittle failure within in situ oceanic crust, $30^{\circ} \mathrm{N}$ Mid-Atlantic Ridge
}

Katsuyoshi Michibayashi, Takehiro Hirose, Toshio Nozaka, Yumiko Harigane, Javier Escartin, Heike Delius, Margaret Linek, Yasuhiko Ohara

\section{To cite this version:}

Katsuyoshi Michibayashi, Takehiro Hirose, Toshio Nozaka, Yumiko Harigane, Javier Escartin, et al. Hydration due to high-T brittle failure within in situ oceanic crust, $30^{\circ} \mathrm{N}$ Mid-Atlantic Ridge. Earth and Planetary Science Letters, 2008, 275 (3-4), pp.348-354. 10.1016/j.epsl.2008.08.033 . hal02330233

\section{HAL Id: hal-02330233 \\ https://hal.science/hal-02330233}

Submitted on 29 Mar 2021

HAL is a multi-disciplinary open access archive for the deposit and dissemination of scientific research documents, whether they are published or not. The documents may come from teaching and research institutions in France or abroad, or from public or private research centers.
L'archive ouverte pluridisciplinaire HAL, est destinée au dépôt et à la diffusion de documents scientifiques de niveau recherche, publiés ou non, émanant des établissements d'enseignement et de recherche français ou étrangers, des laboratoires publics ou privés. 
1

4 15

\section{Hydration due to high-T brittle failure within in situ oceanic crust, $30^{\circ} \mathrm{N}$ Mid-Atlantic Ridge}

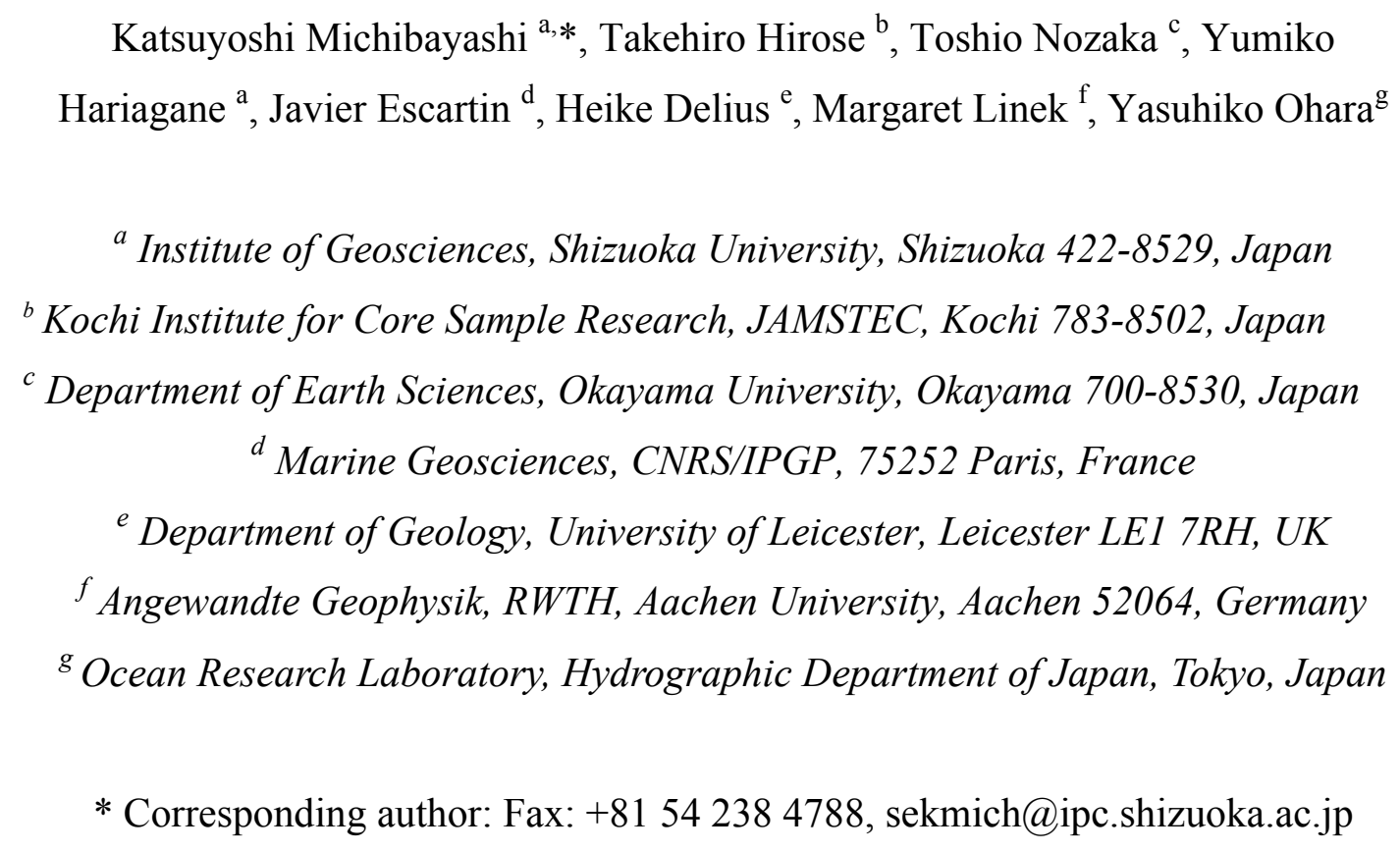

1 Re-submitted to Earth and Planetary Sciences Letters 11 th August 2008 


\section{Abstract}

23 Analysis of an in situ fault zone within the Atlantis Massif oceanic core complex

24 (Mid-Atlantic Ridge) provides clues to the relevant deformation mechanisms and their

25 temporal evolution within oceanic crust. IODP EXP304/305 drilled a succession of

26 gabbroic lithologies to a final depth of 1415 meters below the sea floor (mbsf), with

27 very high recovery rates of up to $100 \%$ (generally $\sim 80 \%$ ). We identified an

28 intra-crustal fault zone between 720 and $780 \mathrm{mbsf}$ in a section of massive gabbro,

29 olivine gabbro, oxide gabbro units, and minor diabase intrusions. Of particular interest

30 is the section between 744 and 750 mbsf, which unfortunately was marked by low

31 recovery rates (17\%). Electrical borehole-wall images show a 1-m-thick zone of

32 east-dipping fractures within this interval, which is otherwise dominated by $\mathrm{N}-\mathrm{S}$

33 dipping structures. Despite the high fracture density in this section, the hole walls are

34 smooth, with rare breakouts, suggesting that the low recovery rate was due to a change

35 in lithology rather than well conditions. The recovered rocks include ultracataclasite

36 and possibly incohesive fault gouge that formed in the upper amphibolite regime, with

37 mostly amphibole infill. Logging data suggest that the gabbroic rocks in this interval

38 are rich in hydrous phases, consistent with increased amounts of amphibole found in

39 the core. Equilibration temperature conditions of about $640^{\circ} \mathrm{C}$ were obtained for

40 plagioclase clasts and aluminous actinolite, assuming a pressure of $200 \mathrm{MPa}$. The

41 permeability of the fault zone is in the range of $10^{-19}$ to $10^{-17} \mathrm{~m}^{2}$. Although the

42 permeability appears to be high within the fault zone relative to other parts of the

43 section, it is no higher than that in typical lower crustal material. As a consequence,

44 because brittle failure occurred at high temperatures, the fault zone was subsequently

45 completely sealed by hydrous minerals, thereby preventing further fluid circulation

46 and preserving water in the crust.

48 Key words: IODP U1309D, Mid-Atlantic Ridge, gabbro, fault, permeability, 49 core-log 


\section{Introduction} oceanic plate subducts at a trench, the hydrated crust carries water in the form of hydrous meta-basalt (e.g., blueschist; Peacock, 1993). The hydrous minerals become unstable at the pressures and temperatures of the shallow subduction zone $(\sim 50 \mathrm{~km}$ depth) and are dehydrated to produce anhydrous eclogitic oceanic crust. This dehydration process is expected to occur at depths of $\sim 50-150 \mathrm{~km}$ in a cold subduction environment such as that beneath Northeast Japan (Hacker et al., 2003; Iwamori and Zhao, 2000; Kita et al., 2006; Tsuji et al., 2008). Because the presence of water substantially lowers the melting temperature of mantle peridotite, it is generally believed that the liberated water eventually triggers mantle melting, thereby generating island arc volcanism (Tatsumi, 1989). This scheme of dehydration of the subducting slab is petrologically and geodynamically well established (e.g., Kawakatsu and Watada, 2007; Iwamori, 2007); however, it remains unknown as to how and where the oceanic crust becomes hydrated.

In this paper, we document the high-T brittle failure and subsequent hydration-reaction-related sealing of a fault zone within young oceanic crust upon 68 the Atlantis Massif, Mid-Atlantic Ridge ( $30^{\circ} 10^{\prime} \mathrm{N}$; Fig. 1) drilled during Expeditions 9304 and 305 of the Integrated Ocean Drilling Program (EXP304/305 IODP; 0 Blackman et al., 2006). The fault zone of interest is located at 746 meters below sea 1 level (mbsf) within massive gabbro suites, and shows no overprinting by 2 exhumation-related structures. A combined study of in situ borehole logging data and 3 analyses of drill core recovered from the fault zone enables us to characterize the 4 fault zone. We argue that the documented hydration processes may occur pervasively 5 within oceanic crust along fault zones beneath the mid-oceanic ridge.

\section{Geological Setting}

The Atlantis Massif, which formed within the past 1.5-2 m.y., bounds the 1 west side of the median valley of the Mid-Atlantic Ridge (Fig. 1). The corrugated, 
82 striated central portion of this domal massif displays morphologic and geophysical

83 characteristics inferred to be representative of an oceanic core complex exposed via 84 long-lived detachment faulting (e.g., Cann et al., 1997; Tucholke et al., 1998; 85 Blackman et al., 1998; Collins et al., 2001; Escartin et al., 2003; Blackman et al., 86 2004). The drill hole analyzed in the present study (EXP304/305 IODP) is located 87 within the footwall of the detachment fault, extending through a succession of 88 gabbroic lithologies down to final depth of 1415 mbsf (Blackman et al., 2006; 89 Ildefonse et al., 2007). The interval between 720 and 780 mbsf, within which the 90 fault zone of the present study occurs, consists of a succession of massive gabbro, 91 olivine gabbro, oxide gabbro, and minor diabase intrusions (Fig. 1). The fault zone 92 consists of three discrete brittle faults, and occurs well below the major detachment 93 fault located at the top of the hole, where brittle and plastic deformation appears to 94 be more intense (Blackman et al., 2006).

\section{Logging Data}

\subsection{Methods}

Downhole logging data are useful in complementing core data (e.g., visual core descriptions, analysis of thin sections) and determining the orientation of structures identified in the recovered core. The coverage of downhole data attained during EXP 304/305 was almost 100\% (Blackman et al., 2006). Standard logs such as density, resistivity, neutron porosity, and natural gamma radiation were collected between depths of 50 and $1415 \mathrm{mbsf}$ at a sampling interval of $0.15 \mathrm{~m}$.

Density was measured using the hostile-environment lithodensity tool 106 (HLDT). In this highly resistive environment, a dual laterolog (DLL) was used to 107 measure resistivity, recording both shallow and deep penetrating resistivity. An 108 accelerator porosity sonde (APS) was used to estimate porosity and degree of 109 alteration. In highly altered rocks, neutron porosity shows a marked increase related 110 to the sensitivity of the tool to hydrogen-rich minerals (e.g., clays, chlorite, and 111 serpentinite) that fill veins and occur as replacement minerals. The 112 hostile-environment spectral gamma ray tool (HNGS) and spectral gamma ray tool 113 (NGT) were used to measure natural radioactivity. The HNGS output was generally 
114 superior to that of NGT, as it was run first and the rocks were not artificially

115 activated by the neutron porosity tool.

116 Formation microscanner (FMS) electric resistivity images were used to assess

117 variations in structure. The FMS is a four-pad microelectrical resistivity device that

118 enables detailed investigations of vertical and lateral variations in formation

119 resistivity (Serra, 1989) with a shallow depth of investigation ( $\sim 2 \mathrm{~mm})$. Data quality

120 is highly sensitive to poor pad contact with the borehole wall arising from surface

121 roughness. The obtained resistivity values are relative because the current flow is

122 continuously adjusted during logging to optimize the operating range of the tool

123 under varying bed resistivity. Resistivity measurements are recorded every $2.5 \mathrm{~mm}$,

124 and the vertical resolution of the tool is in the order of $2.5 \mathrm{~cm}$; it is possible to detect

125 beds thinner than $2.5 \mathrm{~cm}$ if high resistivity contrast exists between the adjacent beds

126 (Serra, 1989). During data processing, images were dynamically normalized over a 2

127 m moving window.

128

129

3.2. Logging Results

130 The quality of the logging data is extremely high for all tools because of the

131 excellent hole conditions encountered during drilling. The density, resistivity, and

132 velocity logs are useful in distinguishing different gabbroic rocks, and are

133 particularly valuable in examining the overall structure, including that in

134 non-recovered sections within the interval around the fault zone. The trends in these

135 datasets are related to alteration and deformation associated with the fault zone (Fig.

136 1).

137 The diameter of the borehole (named as Caliper) varies between 25.46 and

$13831.46 \mathrm{~cm}$ (Fig. 1). The maximum diameter occurs in gabbro at $731.8 \mathrm{mbsf}$, and the

139 minimum in diabase at around 760 mbsf. This interval between 740 and $760 \mathrm{mbsf}$

140 shows a highly smooth surface, with no apparent breakouts despite the low recovery

141 at certain intervals such as the fault zone.

142 The overall neutron porosity within the borehole is generally around 5\%, a

143 typical value for gabbro, although this figure exceeds $10 \%$ in places, including the

144 interval containing the fault zone (Fig. 1). The shallow and deep resistivity decrease

145 from 144 ohm.m in regular gabbro to 28 ohm.m within the fault zone (Fig. 1), and 
146 density decreases from $\sim 2.9 \mathrm{gr} / \mathrm{cm}^{3}$ in regular gabbro to $\sim 2.0 \mathrm{gr} / \mathrm{cm}^{3}$ within the fault 147 zone.

148 Within the fault zone, between 744 and $750 \mathrm{mbsf}$, the electrical horehole wall 149 images reveal an approximately 1-m interval of east-dipping structures between 150 structures that dip to the north and south (Fig. 1).

\section{Core Analyses}

153

Only $0.8 \mathrm{~m}$ of core was recovered from the $4.8 \mathrm{~m}$ interval between 746.2 and 751.0 mbsf (Fig. 1), with most of the core showing intense brittle deformation indicative of cataclasis and ultracataclasis. This section of core is described in detail

\section{7 below.}

\subsection{Microstructural Analyses}

Detailed microstructural observations reveal the occurrence of ultracataclasite within coarse cataclasites (Fig. 2); the ultracataclasite contains local microscopic seams of amphibole (Fig. 2C-F), as described below. The coarse cataclasite contains irregularly shaped clasts of plagioclase and locally amphibole within an altered matrix (Fig. 2B). The coarse plagioclase fragments are fractured and show weak undulose extinction. The amphibole clasts, which are altered clinopyroxene grains, show bending with undulose extinction and microcracks. The altered matrix consists of very fine $(<1 \mathrm{~mm})$ amphibole with no apparent shape-preferred orientation. The sizes of plagioclase clasts decrease toward the ultracataclasite zone (Fig. 2B). Within this zone, relic coarse plagioclase clasts show moderate undulose extinction and are intensely fractured, with offset recorded along some of the fractures.

Seams of amphibole and minor epidote and plagioclase occur within the

172 ultracataclasite zone. Amphibole (001) cleavages are oriented subparallel to the fault

173 plane. The seams are irregularly distributed, but are most common within the zone

174 with the most fine-grained clasts, which they locally anastomose around or cut across

175 (Fig. 2C-F). These relationships indicate that the seams originated from the 176 syntectonic replacement of clasts during brittle deformation (i.e., development of the

177 fault zone). Furthermore, flow structures around epidote and plagioclase grains (see 
178 Fig. 2C-F) indicate that the seams were subsequently plastically deformed, without

179 further brittle deformation.

180

181 4.2. Mineral Chemistry

182 4.2.1. Methods

183 The chemical compositions of minerals within two polished thin sections (TS

184 \#398 and \#399) cut from samples from the fault zone were analyzed using a JEOL

185 JXA-733 electron microprobe with three spectrometers housed at Okayama

186 University, Japan. Operating conditions were an accelerating voltage of $15 \mathrm{kV}$, 187 sample current of 10-20 nA, and a defocused beam of $20 \mu \mathrm{m}$ diameter. Analyzed

188 standards were natural or synthetic oxides and silicates. The applied matrix 189 correction followed that of Bence and Albee (1968), using the alpha factors of 190 Nakamura and Kushiro (1970).

191 4.2.2. Results

192 Representative analyses are listed in Table 1, and the locations of analyzed 193 points are shown in Fig. 3. The fibrous amphibole that forms the thin semas in the 194 ultracataclasite (points A2 and A4 in TS \#398; Table 1 and Fig. 3) has the 195 composition of actinolite (Leake, 1978), but is rich in Al and poor in $\mathrm{Si}(<7.6$ per 196 formula unit) relative to typical greenschist-facies actinolite. Some of the 197 amphibole-like fibrous minerals within the films (points A1, A3, and A5 in TS \#398; 198 Table 1 and Fig. 3) have slightly different compositions from the actinolites, being 199 deficient in total oxides (<93 wt.\%); this may reflect a high $\mathrm{H}_{2} \mathrm{O}$ content. Under the 200 microscope, these grains have lower relief, lower birefringence, and smaller 201 extinction angles than actinolite. These optical characteristics, in combination with 202 the possible enrichment in $\mathrm{H}_{2} \mathrm{O}$, suggest that the actinolitic seams are partly 203 decomposed to a variety of biopyribole due to low-temperature alteration; however, 204 the invariable nature of the ratio of tetrahedral cations to tetrahedral and octahedral 205 cations, $(\mathrm{Si}+\mathrm{Al}) /(\mathrm{Si}+\mathrm{Ti}+\mathrm{Al}+\mathrm{Fe}+\mathrm{Mn}+\mathrm{Mg}+\mathrm{Ca})($ Table 1$)$, suggests that 206 amphibole composition is largely unaffected by alteration (Veblen and Burnham, 207 1978).

208 Fibrous amphibole that coexists with chlorite (point A1 in TS \#399; Table 1 209 and Fig. 3) is similar in Si, Al, and alkali contents to the film-forming aluminous 
210 actinolite, whereas amphibole clasts and fringes around chlorite are highly variable 211 in composition (points A2, A3, and A4 in TS \#399), suggesting chemical

212 disequilibrium at the thin-section scale and variable physical conditions of amphibole

213 formation. In particular, the high $\mathrm{Al}$ and low Si contents of the amphibole clasts

214 suggest that high-temperature metamorphism preceded cataclasis and the formation 215 of ultracataclasite.

216 Plagioclase grains show a bimodal distribution of compositions related to 217 grain size: anorthite contents $[\mathrm{An}=100 * \mathrm{Ca} /(\mathrm{Ca}+\mathrm{Na}+\mathrm{K})]$ are 39-43 and 62-63 in 218 small clasts and large crystals, respectively (Table 1 and Fig. 3). On the basis of 219 textural evidence such as grain size, grain shape, and mode of occurrence, the large 220 plagioclase crystals are considered to be relic crystals that grew at an early stage of 221 igneous crystallization or high-temperature metamorphic crystallization; in contrast, 222 the small clasts formed during brittle deformation associated with chemical 223 adjustment to low-temperature conditions.

224 Plagioclase clasts embedded in the foliated seams (points P1 and P2 in TS 225 \#398) are likely to have formed in equilibrium with the aluminous actinolite, as they 226 are homogeneous in composition and in direct contact with the actinolite (Fig. 3). 227 Using the amphibole-plagioclase thermometer of Holland and Blundy (1994) and 228 assuming a pressure of $200 \mathrm{MPa}$, we calculated equilibration temperature conditions 229 of about $640{ }^{\circ} \mathrm{C}$ for the plagioclase clasts and aluminous actinolite.

\section{Permeability Measurements}

232

\subsection{Experimental Procedure}

234 Permeability measurements were performed on samples collected across the 235 fault zone (Table 2). For gas permeability measurements, the samples were shaped 236 into cylinders with a diameter of $25 \mathrm{~mm}$ and length of $\sim 9 \mathrm{~mm}$ (except for one fragile 237 sample which was cut into a rectangular shape of $20 \times 20 \times 7.1 \mathrm{~mm}$ ) and then dried 238 at $90{ }^{\circ} \mathrm{C}$ in an oven for at least 2 weeks to eliminate pore water. All measurements 239 were conducted using an intra-vessel deformation and fluid-flow apparatus (Hirose 240 and Hayman, 2008). Specimens were jacketed with three layers of polyolefin 241 shrinking tubes to isolate the pores from the confining medium. To evaluate the 
242 evolution of permeability with confining pressure, the pressure was increased in a

243 stepwise manner from $5 \mathrm{MPa}$ up to either 60 or $140 \mathrm{MPa}$ and then decreased back

244 down to $5 \mathrm{MPa}$ (Fig. 4).

245 In measuring permeability, we used the steady-state flow method with 246 nitrogen gas as a pore-fluid medium. A constant pore-pressure gradient of 0.2-2.4

$247 \mathrm{MPa}$ was applied across the specimen, with the volume of gas flowing through the 248 specimen being monitored by soap-film flowmeters. The permeability value, $k$, for

249 the nitrogen gas flow is given by the following equation based on Darcy's law:

$$
k=\frac{2 \eta L Q}{A} \frac{P_{\text {down }}}{P_{u p}^{2}-P_{d o w n}^{2}},
$$

251 where $Q$ is the flow rate, $A$ is the cross-sectional area perpendicular to the flow

252 direction, $L$ is the specimen length parallel to the flow direction, $\eta$ is the viscosity of 253 the pore fluid, and $P_{u p}$ and $P_{\text {down }}$ are the pore pressures in the upper and lower ends of 254 the specimen. The measurable flow rate in the apparatus can be varied from 0.05 to

$2555000 \mathrm{ml} / \mathrm{min}$, which roughly corresponds to permeabilities ranging from $10^{-21}$ to $10^{-16}$ $256 \mathrm{~m}^{2}$ for specimens of this size.

\subsection{Experimental Results}

The permeability values obtained for the regular gabbro and fault rocks as a function of confining pressure are shown in Fig. 4A and B, respectively (see also Table 2). The results show the following trends: (1) host rocks are more impermeable than the fault rocks by more than an order of magnitude; (2) permeability decreases with increasing confining pressure, and tends to be lower during the second pressure cycle; (3) for all specimens, the reduced permeability during pressurization did not recover to the initial values during depressurization. For comparison with the borehole data, Fig. 1 shows permeability data at an effective confining pressure of 20 MPa during the downward pressure cycle, which approximately corresponds to the borehole pressure. The downhole permeability plot shows that the fault zone is relatively permeable compared with adjacent rocks, with a permeability of $10^{-18}$ to 


\section{Interpretation and Discussion}

273

\subsection{Logging Data Across the Fault Zone associated with Fault rocks}

The $0.8 \mathrm{~m}$ of core recovered from the $4.8 \mathrm{~m}$ interval between 746.2 and 751.0 mbsf shows intense brittle deformation indicative of cataclasis and ultracataclasis

277 (Fig. 2). Several pieces of ultracataclasite were obtained from sections of gabbro 278 subject to intense brittle deformation within the fault zone (e.g., Fig. 2A). However, it is difficult to determine the scale of the fault zone, since the rate of core recovery was poor across the fault zone (between 744 and $752 \mathrm{mbsf}$ ). In contrast, a near-complete set of downhole logging data was obtained (Fig. 1).

The borehole condition was as good quality as the smooth borehole width across the fault zone (Fig. 1), indicating that the fault zone appears to be well

284 lithified in spite of the development of fault rocks. However, the other logging data around the core of the fault rocks are remarkably different from the protolith gabbroic rocks in the interval between 720 and 780 mbsf: i.e., the low deep resistivity, the high gamma ray and the high neutron porosity, suggesting that the fault zone contains conductive phases (Fig. 1). This interpretation is further supported by the density data, which show values of $\sim 2.9 \mathrm{gr} / \mathrm{cm}^{3}$ in the gabbro suites, decreasing to $\sim 2.0 \mathrm{gr} / \mathrm{cm}^{3}$ within the fault zone. Although the absolute density is poorly calibrated, this decrease in apparent density might be explained by the relatively high permeability within the fault zone (discussed below) and the presence of hydrous phases such as amphibole. At $745 \mathrm{mbsf}$, where the borehole width data indicate an absence of breakouts, the density is $\sim 2.0 \mathrm{~g} / \mathrm{cm}^{3}$, suggesting that cracks, if present at all, remain closed.

Moreover, the electrical horehole wall images can be analyzed to obtain 297 information on the geometry of lithological contacts and fractures within the fault 298 zone (Fig. 1). The images reveal a distinct dark region at the top of the east-dipping 299 zone at around $745.5 \mathrm{mbsf}$, possibly corresponding to the lowest recorded density of $3002.0 \mathrm{~g} / \mathrm{cm}^{3}$ and the highest neutron porosity of $26 \%$ (Fig. 1). These structures 301 probably reveal the full extent of the fault zone, which on this basis is more than $5 \mathrm{~m}$ 302 wide at around 745 mbsf (Fig. 1). 


\subsection{Permeability of the fault zone: implication for hyrdration in the oceanic crust}

The fault zone consists of cataclasite and ultracataclasite. The ultracataclasite contains seams of amphibole and minor epidote and plagioclase (Fig. 2C-F). Flow structures around epidote and plagioclase grains (Fig. 2C-F) demonstrate that the seams were subsequently plastically deformed, with no apparent brittle deformation. Since these seams appear to have developed at temperatures of around $640{ }^{\circ} \mathrm{C}$ (Fig. 3), these microstructural development would indicate a high temperature brittle failure and subsequent slow slip in the fault zone in association with hydrothermal alteration.

Our laboratory measurements indicate that the permeability of the fault zone is in the order of $10^{-19}$ to $10^{-17} \mathrm{~m}^{2}$, more than an order magnitude higher than that of the host gabbroic rocks (Fig. 4). Because our experiments were performed using small cores that did not contain large-scale fractures, much higher permeabilities are likely within the highly fractured parts of the fault zone that were not recovered during drilling. In fact, high permeability, ranging from $10^{-18}$ to $10^{-13} \mathrm{~m}^{2}$, has been reported from in situ permeability measurements of shallow basaltic oceanic crust within which fractures are favorably developed (see the review by Fisher, 1998). Although large-scale crustal fault zones are likely to be more highly permeable than that indicated by our laboratory results, our relatively low-permeability fault data may represent the permeability structure of minor-scale or locally inactive fault zones such as those likely to be observed within the present cores (Fig. 2). Such a low-permeable fault zone results from progressive sealing via the formation of hydrous minerals at around $640{ }^{\circ} \mathrm{C}$. Given that the amphibole crystals that act as the seal were plastically deformed within the fault zone (Fig. 2), such a low permeability structure within the fault zone, which is as low as that of the lower crust (e.g., Brace, 1984), would occur during the later stages or perhaps even the last stage of fault movement (i.e., a post-seismic event).

We argue that the low-permeable fault zone observed within gabbro in the present study is one of the best candidate structures for preserving water in the oceanic crust. The water could be input into lower crustal rocks to form hydrous minerals along fault zones that developed near the spreading axis presumably during seismic events (e.g., Wolfe et al., 1995) and might then be preserved because of a 
336 low permeability structure, until dehydration reactions occur with increasing

337 temperature at some tectonic settings such as a subducting slab.

\section{Conclusions}

IODP EXP304/305 drilled a succession of gabbroic lithologies to a final depth 342 of 1415 meters below the sea floor (mbsf), attaining very high recovery rates of up to $343100 \%$ (generally $\sim 80 \%$ ). We identified an intra-crustal fault zone between 720 and 780 344 mbsf in a section consisting of massive gabbro, olivine gabbro, oxide gabbro, and 345 minor diabase intrusions. Of particular interest is the section between 744 and 750 346 mbsf, marked by poor core recovery (17\%). Electrical borehole-wall images show a 347 1-m-thick zone of east-dipping fractures within this interval that is otherwise 348 dominated by structures dipping to the $\mathrm{N}$ and $\mathrm{S}$. Despite a high fracture density, the 349 section has smooth walls with rare breakouts, suggesting that the poor recovery is due 350 to a change in lithology rather than well conditions. Ultracataclasite formed in the 351 upper amphibolite regime, with infill dominated by amphibole. Logging data suggest 352 that the gabbroic rocks in this interval are rich in hydrous phases, consistent with the 353 increased amounts of amphibole found in the core. Equilibration temperature 354 conditions of about $640{ }^{\circ} \mathrm{C}$ (assuming a pressure of $200 \mathrm{MPa}$ ) were obtained for 355 plagioclase clasts and aluminous actinolite. Laboratory experiments reveal that the 356 permeability of the fault zone is in the range of $10^{-19}$ to $10^{-17} \mathrm{~m}^{2}$. Although the 357 permeability is relatively high within the fault zone, the overall permeability structure 358 is no higher than that in the lower crust; consequently, because brittle failure occurred 359 at high temperatures, the fault zone was subsequently completely sealed with hydrous 360 minerals, thereby preventing further fluid circulation. Such low-permeable fault zone 361 observed within gabbro in the present study is one of the best candidate structures for 362 preserving water in the oceanic crust.

\section{Acknowledgements}

365 This research used samples and data provided by the Integrated Ocean 366 Drilling Program (IODP) and the shipboard parties of Expedition 304/305. We thank 367 C. P. Jaupart and an anonymous reviewer for their valuable comments and A. 
Stallard for improving the English in the manuscript. We thank the Integrated Ocean Drilling Program for their extraordinary efforts during Exp 304/305. This study was supported by research grants from the Japan Society for the Promotion of Science (JSPS) and the Japan Drilling Earth Science Consortium (J-DESC).

\section{References}

Barclay, A.H., Toomey, D.R., Solomon, S.C., 2001. Microearthquake characteristics and crustal Vp/Vs structure at the Mid-Atlantic Ridge, $35^{\circ}$ N. J. Geophys. Res. 106, 2017-2034.

Bence, A.E., Albee, A.L., 1968. Empirical correction factors for the electron microanalysis of silicates and oxides. J. Geol. 76, 382-403.

Blackman, D.K., Cann, J.R., Janssen, B., and Smith, D.K., 1998. Origin of extensional core complexes: evidence from the MAR at Atlantis Fracture Zone. J. Geophys. Res. 103, 21315-21334.

Blackman, D.K., Karson, J.A., Kelley, D.S., Cann, J.R., Früh-Green, G.L., Gee, J.S., Hurst, S.D., John, B.E., Morgan, J., Nooner, S.L., Ross, D.K., Schroeder, T.J., Williams, E.A., 2004. Geology of the Atlantis Massif (MAR $\left.30^{\circ} \mathrm{N}\right)$ : implications for the evolution of an ultramafic oceanic core complex. Mar. Geophys. Res. 23, $443-469$.

Blackman, D.K., Ildefonse, B., John, B.E., Ohara, Y., Miller, D.J., MacLeod, C.J., and Expedition 304/305 Scientists, 2006, Proceedings of the Integrated Ocean Drilling Program, Volume 304/305: College Station, Texas, Integrated Ocean Drilling Program Management International, Inc., doi:10.2204/iodp.proc.304305.2006.

Brace, W.F., 1984. Permeability of crystalline rocks - new insitu measurements. J. Geophys. Res. 89, 4327-4330.

Cann, J.R., Blackman, D.K., Smith, D.K., McAllister, E., Janssen, B., Mello, S., Avgerinos, E., Pascoe, A.R., Escartin, J., 1997. Corrugated slip surfaces formed at ridge-transform intersections on the Mid-Atlantic Ridge. Nature 385, 329-332.

Collins, J.A., Tucholke, B.E., Canales, J.-P., 2001. Structure of Mid-Atlantic Ridge megamullions from seismic refraction experiments and multichannel seismic 
reflection profiling. Eos, Trans. Am. Geophys. Union 82, F1100.

Escartin, J., Mével, C., MacLeod, C.J., McCaig, A.M., 2003. Constrains on deformation conditions and the origin of oceanic detachments: The Mid-Atlantic Ridge core complex at $15^{\circ} 45^{\prime} \mathrm{N}$. Geochem. Geophys. Geosyst. 4, 1067, doi:10.1019/2002GC000472, 2003.4

Fisher, A.T., 1998. Permeability within basaltic oceanic crust. Rev. Geophys. 36, 143-182.

Hacker, B.R., Peacock, S.M., Abers, G.A., Holloway, S.D., 2003. Subduction factory: 2. Are intermediate-depth earthquakes in subducting slabs linked to metamorphic dehydration reactions? J. Geophys. Res., 108, 2030, doi:10.1029/2001JB001129.

Hirose, T., Hayman, N.W., 2008. Structure, permeability, and strength of a fault zone in the footwall of an oceanic core complex, the Central Dome of the Atlantis Massif, Mid-Atlantic Ridge, $30^{\circ}$ N. J. Struct. Geol. 30, 1060-1071.

Holland, T., Blundy, J., 1994. Non-ideal interactions in calcic amphiboles and their bearing on amphibole-plagioclase thermometry. Contrib. Miner. Petrol. 116, 433-447.

Ildefonse, B., Blackman, D.K., John, B.E., Ohara, Y., Miller, D.J., MacLeod, C.J. and Integrated Ocean Drilling Program Expeditions 304/305 Science Party, 2006. Oceanic core complexes and crustal accretion at slow-spreading ridges. Geology, $35,623-626$.

Iwamori, H., 2007. Transportation of $\mathrm{H}_{2} \mathrm{O}$ beneath the Japan arcs and its implications for global water circulation. Chem. Geol. 239, 182-198.

Iwamori, H., Zhao, D., 2000. Melting and seismic structure beneath the northeast Japan arc. Geophys. Res. Lett. 27, 425-428.

Kawakatsu, H., Watada, S., 2007. Seismic evidence for deep-water transportation in the mantle. Science, 316, 1468, doi: 10.1126/science. 1140855.

Kita, S., Okada, T., Nakajima, J., Matsuzawa, T., Hasegawa, A., 2006. Existence of a seismic belt in the upper plane of the double seismic zone extending in the along-arc direction at depths of 70-100 km beneath NE Japan. Geoph. Res. Lett., 33, L24310, doi: 10.1029/2006GL028239.

Leake, B.E., 1978. Nomenclature of amphiboles. Mineralogical Magazine, 42, 
431

432

433

434

435

436

437

438

439

440

441

442

443

444

445

446

447

448

449

450

451

452

453

454

533-563.

Nakamura, Y., Kushiro, I., 1970. Compositional relations of coexisting orthopyroxene, pigeonite and augite in a tholeiitic andesite from Hakone volcano. Contrib. Miner. Petrol. 26, 265-275.

Peacock, S.M., 1993. Large-scale hydration of the lithosphere above subducting slabs. Chem. Geol., 108, 49-59.

Serra, O., 1989. Formation MicroScanner Image Interpretation: Houston (Schlumberger Educ. Services), SMP-7028.

Tatsumi, Y., 1989. Migration of fluid phases and genesis of basalt magmas in subduction zones. J. Geophys. Res. 94, 4697-4707.

Tsuji, Y., Nakajima, J., Hasegawa, A., 2008. Tomographic evidence for hydrated oceanic crust of the Pacific slab beneath northeastern Japan: Implications for water transportation in subduction zones. Geophys. Res. Lett., 35, L15308, doi: 10.1029/2008GL034461.

Tucholke, B.E., Lin, J., Kleinrock, M.C., 1998. Megamullions and mullion structure defining oceanic metamorphic core complexes on the mid-Atlantic ridge: J. Geophys. Res. 103, 9857-9866, doi:10.1029/98JB00167.

Veblen, D.R., Burnham, C.W., 1978. New biopyriboles from Chester, Vermont: I. Descriptive mineralogy. Amer. Mineral., 63, 1000-1009.

Wolfe, C.J., Purdy, G.M., Toomey, D.R., Solomon, S.C., 1995. Microearthquake chracteristics and crustal velocity structure at $29^{\circ} \mathrm{N}$ on the Mid-Atlantic Ridge: The architecture of a slow spreading segment. J. Geophys. Res. 100, 24449-24472. 
$455 \quad$ Figure captions

456

457 Figure 1.

458 Borehole data for the interval between 720 and 780 mbsf within Hole 459 U1309D drilled by IODP Expeditions 304 and 305. The fault zone occurs in the 460 interval between 746.2 and $751.0 \mathrm{mbsf}$ (colored in yellow), for which permeability 461 measurements were performed. A distinct dark layer occurs at the top of the 462 east-dipping zone at around 745.5 mbsf, from where core was not recovered (colored 463 in pink). See the text for details.

464

465 Figure 2.

(A) Ultracataclasite recovered from Core U1309D 152R1 (for sample 467 location within the borehole, see the right-hand side of Fig. 1). An apparent reverse 468 sense of movement (white arrows) is apparent from the geometries of asymmetric 469 fragments. The white rectangle represents the area from which a thin section was made. (B) Microphotograph of the entire thin section cut from the area indicated by the rectangle in A. Width: $3 \mathrm{~cm}$. Cataclasite consists of plagioclase and amphibole 472 fragments in a matrix of amphibole. Black rectangles show the areas enlarged in $\mathrm{C}$ and F. (C)

(C)

Amphibole-dominated films within the ultracataclasite.

(D) and (E)

474 Enlargements of the amphibole-dominated films shown in C, showing flow 475 structures around epidote (EP) and plagioclase grains. (F) Enlargement of the amphibole-dominated films shown in B. Very fine-grained fragments were replaced by the amphibole films.

479 Figure 3.

Points selected for EPMA analysis shown on a BEI image of the amphibole films shown in Fig. 2C. A: amphibole, Pl: plagioclase, E: epidote. Representative results of the analyses are listed in Table. 1.

484 Figure 4.

Gas permeability data as a function of effective pressure for host rocks (A) 
486 and fault rocks (B) (see Table 2 for summary). Data are the average values of four 487 measurements. Error bars are smaller than the data symbols. 

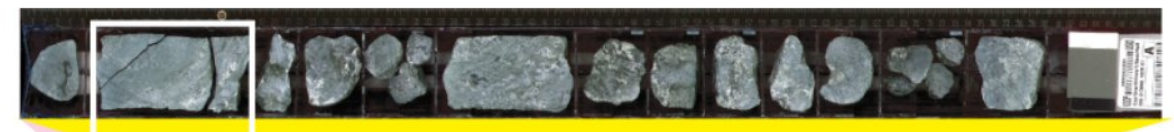

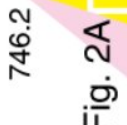

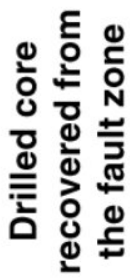
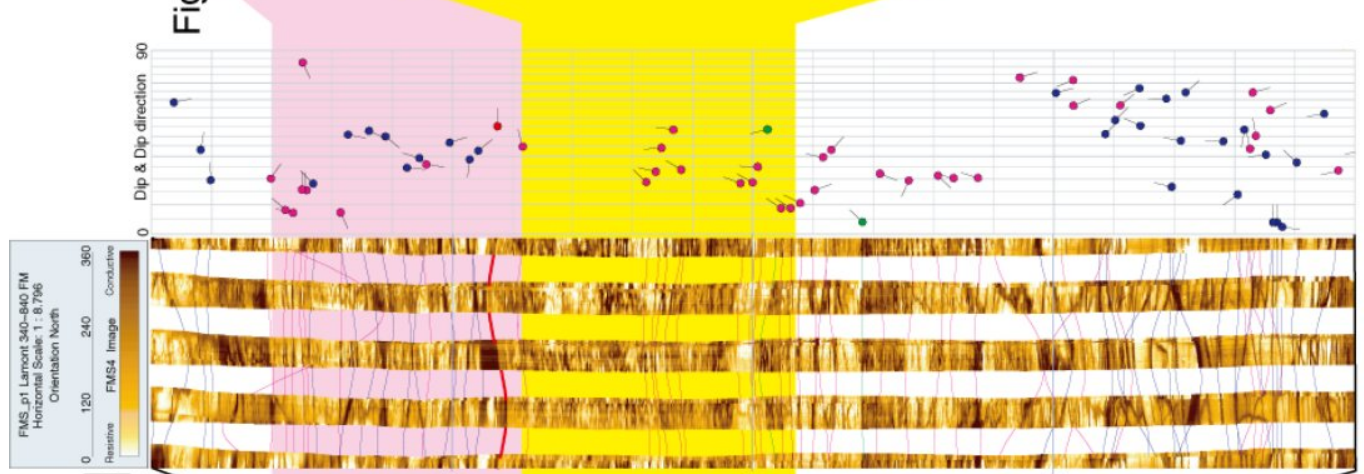

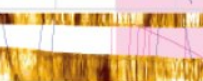

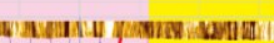

$0^{\circ}$

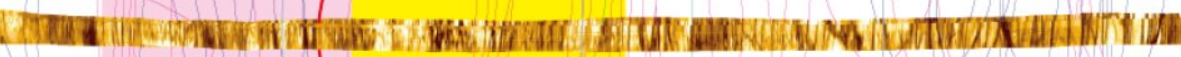

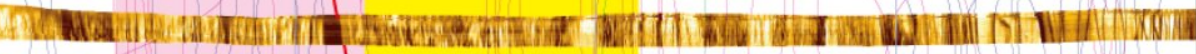

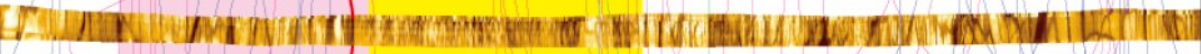

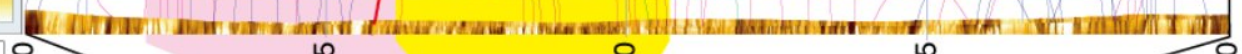

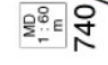
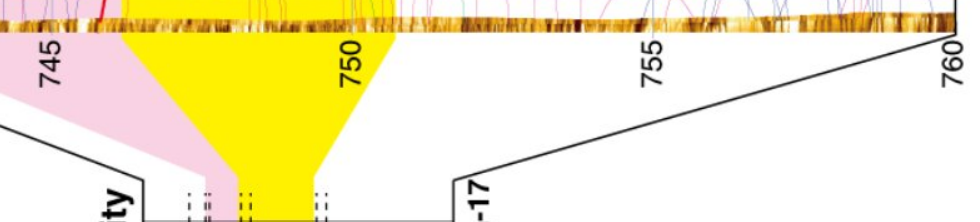

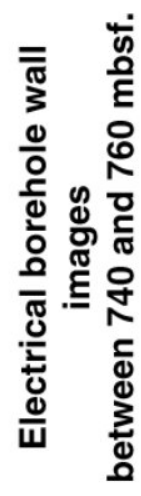

2

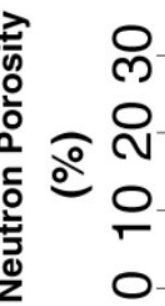

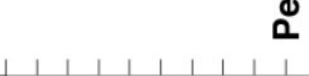

ฮ ำ 음

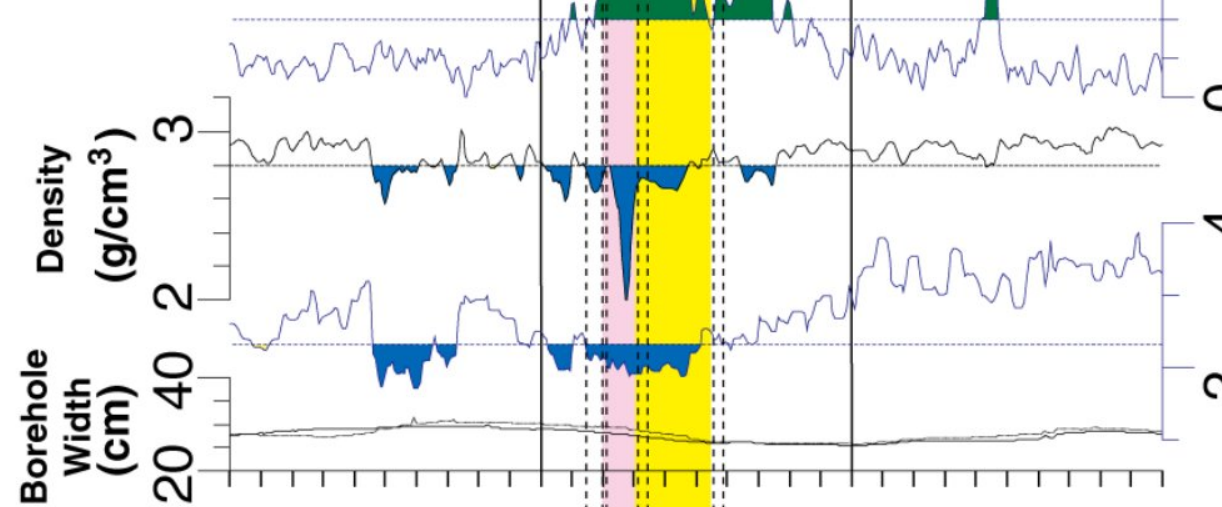

6
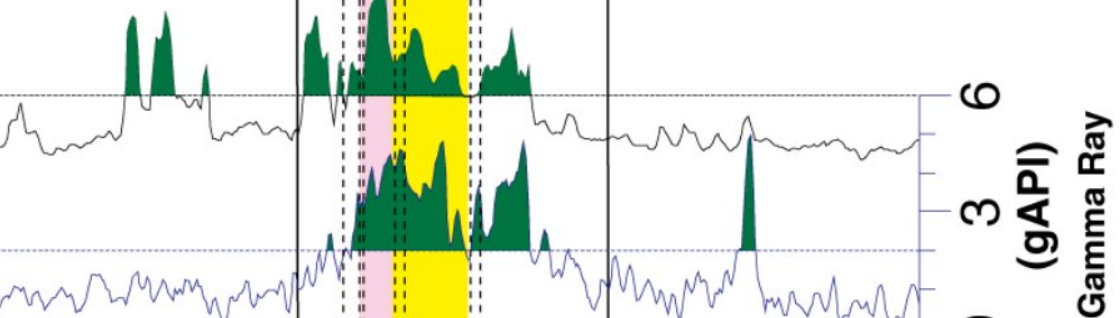

$\circ$

-

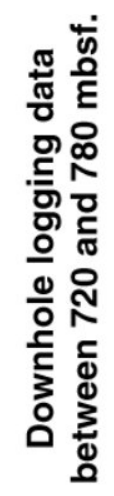

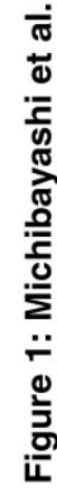

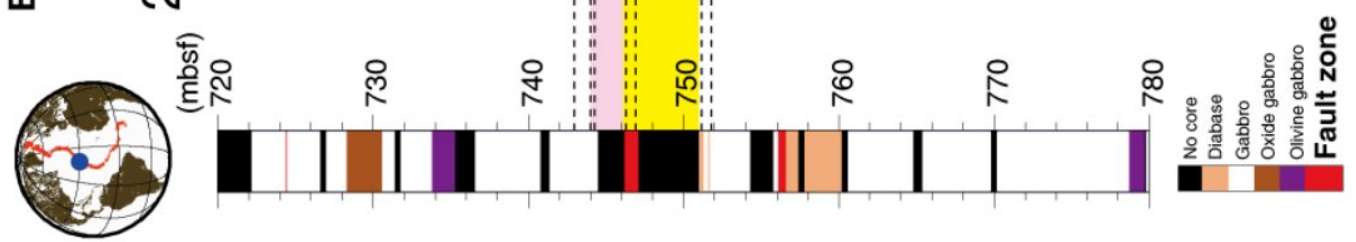




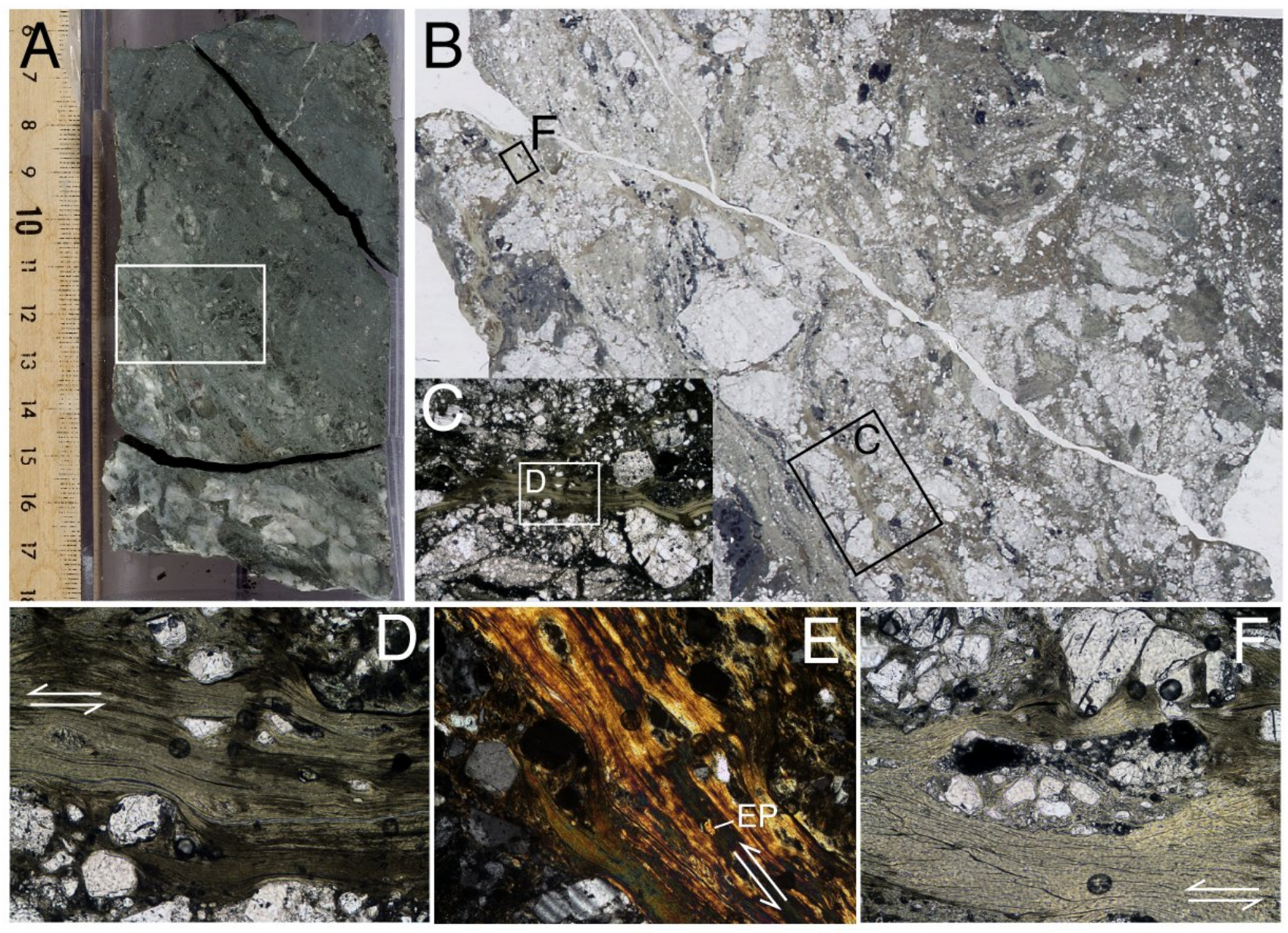

Figure 2. (A) Ultracataclasite recovered from Core U1309D 152R1 (for sample location within the borehole, see the right-hand side of Fig. 1). An apparent reverse sense of movement (white arrows) is apparent from the geometries of asymmetric fragments. The white rectangle represents the area from which a thin section was made. (B) Microphotograph of the entire thin section cut from the area indicated by the rectangle in A. Width: $3 \mathrm{~cm}$. Cataclasite consists of plagioclase and amphibole fragments in a matrix of amphibole. Black rectangles show the areas enlarged in C and F. (C) Amphibole-dominated films within the ultracataclasite. (D) and (E) Enlargements of the amphibole-dominated films shown in C, showing flow structures around epidote (EP) and plagioclase grains. (F) Enlargement of the amphibole-dominated films shown in B. Very fine-grained fragments were replaced by the amphibole films. 


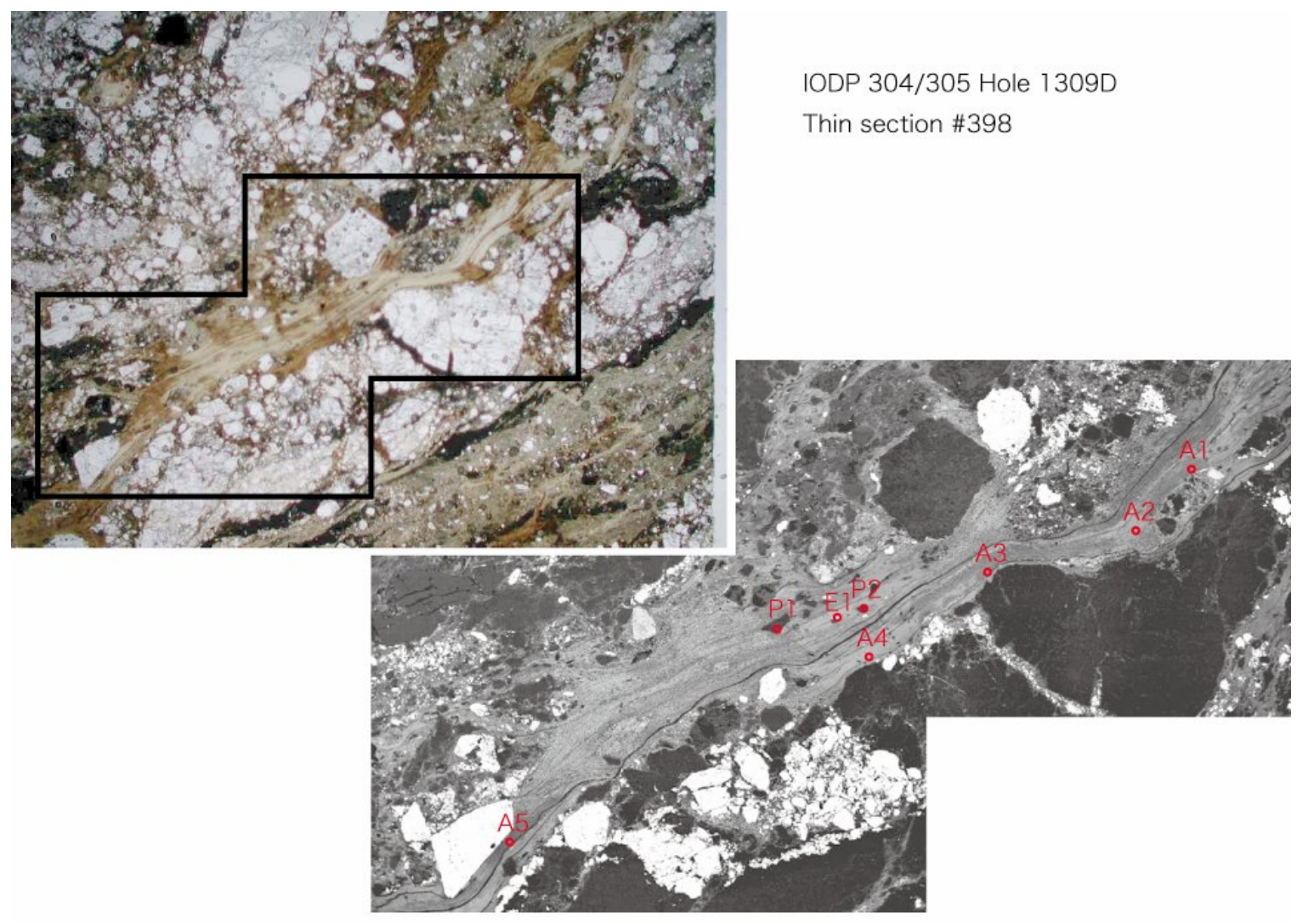

Figure 3. Points selected for EPMA analysis shown on a BEI image of the amphibole films shown in Fig. 2C. A: amphibole, Pl: plagioclase, E: epidote. Representative results of the analyses are listed in Table. 1. 


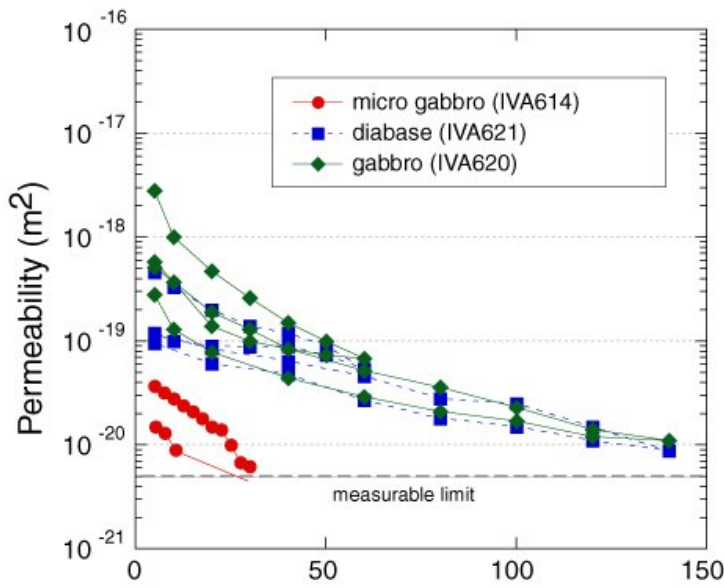

(A)

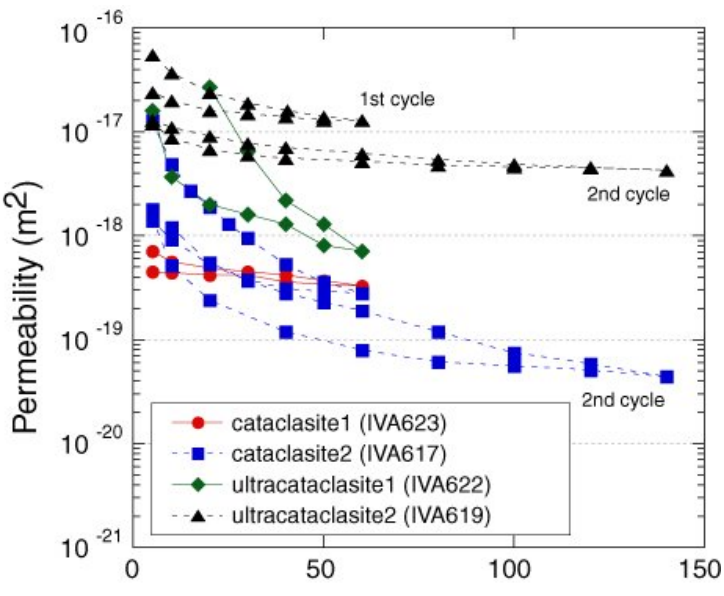

(B)

Effective pressure (MPa)

Figure 4. Gas permeability data as a function of effective pressure for host rocks (A) and fault rocks (B) (see Table 2 for summary). Data are the average values of four measurements. Error bars are smaller than the data symbols. 
Table 1. Chemical compositions of minerals.

\begin{tabular}{|c|c|c|c|c|c|c|c|c|c|c|c|c|c|c|c|c|c|c|}
\hline $\begin{array}{l}\text { Thin Section No. } \\
\text { Sample No. }\end{array}$ & $\begin{array}{r}398 \\
\mathrm{~A} 1 \\
\end{array}$ & $\begin{array}{r}398 \\
\text { A2 }\end{array}$ & $\begin{array}{r}398 \\
\mathrm{~A} 3 \\
\end{array}$ & $\begin{array}{r}398 \\
\mathrm{~A} 4 \\
\end{array}$ & $\begin{array}{r}398 \\
\text { A5 }\end{array}$ & $\begin{array}{r}398 \\
E 1\end{array}$ & $\begin{array}{l}398 \\
\text { PI1 }\end{array}$ & $\begin{array}{r}398 \\
\mathrm{PI} 2\end{array}$ & $\begin{array}{r}399 \\
\text { Chl1 } \\
\end{array}$ & $\begin{array}{r}399 \\
\text { Chl2 }\end{array}$ & $\begin{array}{r}399 \\
\text { Am1 } \\
\end{array}$ & $\begin{array}{r}399 \\
\text { Am2 } \\
\end{array}$ & $\begin{array}{r}399 \\
\text { Am3 } \\
\end{array}$ & $\begin{array}{r}399 \\
\text { Am4 } \\
\end{array}$ & $\begin{array}{l}399 \\
\text { Pl1 }\end{array}$ & $\begin{array}{r}399 \\
\mathrm{PI} 2\end{array}$ & $\begin{array}{r}399 \\
\mathrm{PI} 3\end{array}$ & $\begin{array}{r}399 \\
\mathrm{P} 14 \\
\end{array}$ \\
\hline $\mathrm{SiO} 2$ & 49.76 & 52.06 & 49.77 & 51.66 & 47.94 & 35.55 & 57.77 & 58.17 & 26.00 & 26.12 & 51.18 & 49.89 & 46.97 & 51.84 & 52.14 & 51.76 & 57.48 & 57.65 \\
\hline $\mathrm{TiO} 2$ & 0.17 & 0.17 & 0.16 & 0.17 & 0.11 & 0.07 & nd & nd & 0.06 & 0.07 & 0.34 & 0.31 & 0.82 & 0.09 & nd & nd & nd & nd \\
\hline $\mathrm{Al} 2 \mathrm{O} 3$ & 3.39 & 3.69 & 3.47 & 3.99 & 3.83 & 22.11 & 27.26 & 27.05 & 19.60 & 19.36 & 2.76 & 5.36 & 5.92 & 1.38 & 28.81 & 28.57 & 25.10 & 25.25 \\
\hline $\mathrm{FeO} *$ & 12.17 & 12.93 & 12.80 & 13.51 & 13.85 & & nd & nd & 23.19 & 23.03 & 19.55 & 17.16 & 24.81 & 21.46 & nd & nd & nd & nd \\
\hline $\mathrm{Fe} 2 \mathrm{O} 3 * *$ & & & & & & 13.36 & & & & & & & & & & & & \\
\hline $\mathrm{MnO}$ & 0.15 & 0.21 & 0.22 & 0.29 & 0.23 & 0.16 & nd & nd & 0.21 & 0.22 & 0.39 & 0.14 & 0.79 & 0.58 & nd & nd & nd & nd \\
\hline $\mathrm{MgO}$ & 15.15 & 15.87 & 14.62 & 15.59 & 13.99 & 0.11 & nd & nd & 17.80 & 18.24 & 11.66 & 12.46 & 8.83 & 11.53 & nd & nd & nd & nd \\
\hline $\mathrm{CaO}$ & 11.22 & 11.69 & 11.06 & 10.89 & 10.02 & 19.63 & 8.56 & 8.57 & 0.08 & 0.12 & 11.91 & 12.26 & 9.48 & 11.41 & 12.99 & 13.13 & 8.66 & 8.84 \\
\hline $\mathrm{Na} 2 \mathrm{O}$ & 0.32 & 0.40 & 0.36 & 0.48 & 0.61 & 0.00 & 6.64 & 7.47 & 0.00 & 0.01 & 0.30 & 0.65 & 1.03 & 0.21 & 4.26 & 4.22 & 6.60 & 6.55 \\
\hline K2O & 0.04 & 0.04 & 0.03 & 0.07 & 0.06 & 0.04 & 0.08 & 0.07 & 0.01 & 0.02 & 0.05 & 0.04 & 0.12 & 0.06 & 0.06 & 0.04 & 0.10 & 0.08 \\
\hline total & 92.37 & 97.06 & 92.49 & 96.65 & 90.64 & 91.03 & 100.31 & 101.33 & 86.95 & 87.19 & 98.14 & 98.27 & 98.77 & 98.56 & 98.26 & 97.72 & 97.94 & 98.37 \\
\hline Cations $/ \mathrm{O}=$ & 23 & 23 & 23 & 23 & 23 & 12.5 & 8 & 8 & 7 & 7 & 23 & 23 & 23 & 23 & 8 & 8 & 8 & 8 \\
\hline $\mathrm{Si}$ & 7.578 & 7.555 & 7.591 & 7.539 & 7.510 & 3.029 & 2.576 & 2.576 & 1.369 & 1.371 & 7.600 & 7.329 & 7.133 & 7.725 & 2.407 & 2.404 & 2.627 & 2.624 \\
\hline $\mathrm{Ti}$ & 0.020 & 0.018 & 0.018 & 0.018 & 0.014 & 0.004 & nd & nd & 0.002 & 0.003 & 0.038 & 0.034 & 0.094 & 0.010 & nd & nd & nd & nd \\
\hline Al & 0.609 & 0.631 & 0.623 & 0.687 & 0.706 & 2.220 & 1.433 & 1.412 & 1.216 & 1.198 & 0.484 & 0.928 & 1.060 & 0.243 & 1.567 & 1.564 & 1.352 & 1.354 \\
\hline $\mathrm{Fe}$ & 1.550 & 1.570 & 1.633 & 1.649 & 1.815 & 0.856 & nd & nd & 1.021 & 1.011 & 2.428 & 2.108 & 3.150 & 2.674 & nd & nd & nd & nd \\
\hline $\mathrm{Mn}$ & 0.019 & 0.026 & 0.029 & 0.036 & 0.030 & 0.012 & nd & nd & 0.010 & 0.010 & 0.049 & 0.017 & 0.102 & 0.074 & nd & nd & nd & nd \\
\hline $\mathrm{Mg}$ & 3.440 & 3.434 & 3.325 & 3.392 & 3.268 & 0.014 & nd & nd & 1.397 & 1.427 & 2.581 & 2.729 & 1.998 & 2.561 & nd & nd & nd & nd \\
\hline $\mathrm{Ca}$ & 1.830 & 1.818 & 1.806 & 1.703 & 1.681 & 1.810 & 0.409 & 0.407 & 0.004 & 0.007 & 1.894 & 1.929 & 1.543 & 1.822 & 0.642 & 0.654 & 0.424 & 0.431 \\
\hline $\mathrm{Na}$ & 0.094 & 0.112 & 0.106 & 0.136 & 0.186 & 0.000 & 0.574 & 0.641 & 0.000 & 0.001 & 0.086 & 0.186 & 0.303 & 0.060 & 0.381 & 0.380 & 0.584 & 0.578 \\
\hline $\mathrm{K}$ & 0.008 & 0.007 & 0.005 & 0.013 & 0.011 & 0.004 & 0.004 & 0.004 & 0.001 & 0.002 & 0.009 & 0.008 & 0.023 & 0.011 & 0.004 & 0.002 & 0.006 & 0.005 \\
\hline Total & 15.148 & 15.171 & 15.136 & 15.173 & 15.221 & 7.950 & 4.996 & 5.040 & 5.020 & 5.030 & 15.169 & 15.268 & 15.406 & 15.180 & 5.001 & 5.004 & 4.993 & 4.992 \\
\hline $\mathrm{Mg \#}$ & 68.9 & 68.6 & 67.1 & 67.3 & 64.3 & & & & 57.8 & 58.5 & 51.5 & 56.4 & 38.8 & 48.9 & & & & \\
\hline An & & & & & & & 41.4 & 38.7 & & & & & & & 62.5 & 63.1 & 41.8 & 42.5 \\
\hline SA/STAFMMC & 0.54 & 0.54 & 0.55 & 0.55 & 0.55 & & & & & & 0.54 & 0.55 & 0.54 & 0.53 & & & & \\
\hline
\end{tabular}

$\mathrm{PI}=$ plagioclase, $\mathrm{Chl}=$ chlorite, $\mathrm{Am}=$ amphibole, $\mathrm{A}=$ amphibole or amphibole-like phase, $\mathrm{E}=$ epidote or epidote-like phase

* total iron as $\mathrm{FeO}$

** total iron as $\mathrm{Fe} 2 \mathrm{O} 3$

nd $=$ not determined

$\mathrm{Mg} \#=100 * \mathrm{Mg} /(\mathrm{Mg}+\mathrm{Fe})$

$\mathrm{A}_{n}=100 * \mathrm{Ca} /(\mathrm{Ca}+\mathrm{Na}+\mathrm{K})$

$\mathrm{SA} / \mathrm{STAFMMC}=(\mathrm{Si}+\mathrm{Al}) /(\mathrm{Si}+\mathrm{Ti}+\mathrm{Al}+\mathrm{Fe}+\mathrm{Mn}+\mathrm{Mg}+\mathrm{Ca})$ 
Table 2. Summary of laboratory-derived permeability data reported in this study.

\begin{tabular}{|c|c|c|c|c|c|c|c|c|c|c|}
\hline core & section & inte & & mbsf & lithology & run no. & $\begin{array}{c}\text { confining } \\
\text { pressure }(\mathrm{Pc}) \\
\text { path } \\
\mathrm{MPa}\end{array}$ & $\begin{array}{c}\text { pore } \\
\text { pressure } \\
(\mathrm{Pp}) \\
\mathrm{MPa}\end{array}$ & $\begin{array}{c}\text { Permeability } \\
\text { at Pc of } 20 \\
\mathrm{MPa}^{*} \\
\mathrm{~m} 2\end{array}$ & remarks \\
\hline \multirow[t]{3}{*}{151} & 2 & 36 & 39 & 743 & micro gabbro & IVA614 & $5-60-5$ & 2.4 & $6.0 \mathrm{E}-21$ & lower than measurable limit \\
\hline & 2 & 101 & 103 & 744 & cataclasite1 & IVA623 & $5-60-5$ & 2.4 & $4.2 \mathrm{E}-19$ & \\
\hline & 3 & 1 & 3 & 744.3 & cataclasite2 & IVA617 & $5-60-5-140-5$ & $0.2-2.4$ & $2.4 \mathrm{E}-19$ & 2 Pc cycles, test with different Pp \\
\hline \multirow[t]{2}{*}{152} & 1 & 7 & 11 & 746.3 & ultracataclasite 1 & IVA622 & $5-60-5$ & 2.4 & 2.7E-17 & rectangular shape sample \\
\hline & 1 & 75 & 77 & 745 & ultracataclasite2 & IVA619 & $5-60-5-140-5$ & $0.3-2.4$ & $6.8 \mathrm{E}-18$ & 2 Pc cycles, test with different Pp \\
\hline \multirow[t]{2}{*}{153} & 1 & 20 & 23 & 751.2 & diabase & IVA621 & $5-60-5-140-5$ & 2.4 & $6.1 \mathrm{E}-20$ & 2 Pc cycles \\
\hline & 1 & 75 & 77 & 751.8 & gabbro & IVA620 & $5-60-5-140-5$ & 2.4 & $7.8 E-20$ & 2 Pc cycles \\
\hline
\end{tabular}

* Permeability data at second depressurization path with pore pressure of $2.4 \mathrm{MPa}$ 